\title{
Incidence, prevalence and coronary heart disease risk level in known Type 2 diabetes: a sentinel practice network study in the Basque Country, Spain
}

\author{
J. M. Arteagoitia1, M. I. Larrañaga'1, J. L. Rodriguez ${ }^{1}$, I. Fernandez ${ }^{1}$, J. A. Piniés ${ }^{2}$ \\ ${ }^{1}$ Epidemiology Unit, Public Health Service, Department of Health, Basque Government, Vitoria-Gasteiz, Spain \\ ${ }^{2}$ Endocrinology and Metabolism Department, Cruces Hospital, Osakidetza-Basque Country Health Service, Baracaldo, \\ Vizcaya, Spain
}

\section{Abstract}

Aims/hypothesis. The aim of this study was to determine the incidence, prevalence and coronary heart disease risk in patients with known Type 2 (non-insulindependent) diabetes mellitus in a Basque Country sentinel practice network study.

Methods. During the year 2000 we did a survey among sentinel practitioners who registered information about previously and newly diagnosed Type 2 diabetic patients older than 24 years of age. We studied 65,651 people attending a primary care service in the Basque Country Health Service-Osakidetza. We collected information about diabetic complications and cardiovascular risk factors and measured the coronary heart disease risk in these patients.

Results. In the year 2000, the standardized cumulative incidence and prevalence of known Type 2 diabetes were 5.0 per 1000 (CI 95\%: 4.9-5.1) and 4.6\% (CI 95\%: 4.5-4.7) respectively. Macroangiopathy was the most frequent complication both in the newly diagnosed $(21.6 \%)$ and previously known Type 2 diabetic patients $(33 \%)$. Total cholesterol $\geq 5.17 \mathrm{mmol} / \mathrm{l}$ and LDL cholesterol $\geq 2.58 \mathrm{mmol} / 1$ were found in $75 \%$ and $90 \%$ of newly diagnosed and $65 \%$ and $85 \%$ of previously diagnosed Type 2 diabetic patients respectively. Of the Type 2 diabetic patients $42 \%$ were obese and $80 \%$ had high blood pressure. More than $55 \%$ of the men compared with $44 \%$ of the women with Type 2 diabetes had high or very high risk of coronary heart disease $(p<0.05)$.

Conclusion/interpretation. We report new epidemiological data on known Type 2 diabetes in the Basque Country. These patients have a high frequency of cardiovascular risk factors causing a high coronary heart disease risk. [Diabetologia (2003) 46:899-909]

Keywords Type 2 diabetes, incidence, prevalence, complications, risk factors, cardiovascular disease, coronary heart disease risk level
Received: 22 January 2003 / Revised: 8 April 2003

Published online: 27 June 2003

C) Springer-Verlag 2003

Corresponding author: Dr. J. M. Arteagoitia, Epidemiology Unit, Public Health Service, Department of Health, Basque Government, C/ Donostia-San Sebastián 1, 01010 VitoriaGasteiz, Spain

E-mail: vigipro1-san@ej-gv.es

Abbreviations: WHO MSVDD, Word Health Organization Multinational Study of Vascular Disease in Diabetes; UKPDS, United Kingdom Prospective Diabetes Study; MRFIT, Multiple Risk Factor Intervention Trial.

The authors wrote this article on behalf of and with the assistance of the Basque Country Sentinel Practice Surveillance Network: see acknowledgements for list of investigators
Type 2 (non-insulin-dependent) diabetes mellitus is a progressive chronic disease with long-term complications causing high associated morbidity and a considerable economic and social burden [1,2,3]. Diabetic patients often develop cardiovascular disease and it is the main cause of the high risk of premature death in these patients $[4,5,6,7]$. The prevalence of diabetes is increasing due to a combination of hereditary, environmental and demographic factors [8]. To deal with this situation, it is essential for public health systems to know not only the frequency of Type 2 diabetes, but also the prevalence of long-term complications and the risk factors associated with the disease. Few surveys of the diabetic population exist in Spain and data about diabetic complications and cardiovascular risk 
factors need to be characterized better, according to the new recommended targets for metabolic control. Furthermore, until now risk factor guidelines for Type 2 diabetes have been done based on unifactorial assessments of hypertension, hyperlipidaemia, and smoking [9]. This approach has underestimated the real cardiovascular risk of Type 2 diabetic patients. We have measured the overall risk of coronary heart disease of known Type 2 diabetic patients of the Basque Country based on the combination of all of these major risk factors.

The effectiveness of the different interventions carried out by primary care professionals to improve the management of diabetic patients depends on the reduction of the high cardiovascular risk in these patients [10]. We have studied the incidence, prevalence, complications, and cardiovascular risk factors of known Type 2 diabetes in the Basque Country in northern Spain. Furthermore, we have calculated the risk of coronary heart disease (CHD) in a known Type 2 diabetic population.

\section{Subjects and methods}

During the year 2000, a diabetes surveillance system was set up in The Basque Country based on a sentinel practice network. This network is an epidemiological surveillance system based on the voluntary collaboration of primary care professionals [11, 12]. Our network was founded in 1986, and has been involved in different collaborative projects with other Spanish and European networks [13, 14]. Primary care physicians play an important role in the Basque Country Health Service, where health care is free and available to the whole population in the Basque Autonomous Region (2,100,000 inhabitants). Each primary care physician is assigned a group of people to take care of within a specific area and this is revised annually.

Sixty-one physicians $(5.5 \%$ of the primary care physicians in the Basque Country Health Service-Osakidetza) participated in attending 65,651 people (4\% of the population older than 24 years of age in the Basque Country). All Health Service areas of the Basque Country were represented in the study. The physicians participating in the study had the same age and sex distribution as the Basque Country primary care physicians. Furthermore, the study sample followed a similar age and sex dis- tribution to the Basque Country population (Table 1). Prevalence and annual cumulative incidence were adjusted by age and sex distribution of the Basque population.

Sentinel physicians recorded information during the year 2000 about previously and newly diagnosed Type 2 diabetic patients older than 24 years of age. Newly Type 2 diabetic patients or incident cases were defined as people who were not diabetic before January 1st 2000 and were diagnosed with Type 2 diabetes during the year 2000. Prevalent cases were considered to be those patients with Type 2 diabetes diagnosed before and during the mid-year 2000. We estimated the point prevalence with reference to mid-year 2000 (July 1st 2000). Type 2 diabetes was diagnosed according to the diagnostic criteria set out by the in 1985 until 1998 [15]. From then on the new diagnostic criteria of the World Health Organisation (WHO) were used [16].

All diabetic patients were registered using a standardised form. The standardised questionnaire included data on chronic diabetic complications, and clinical risk factors. A blood sample for biochemistry was obtained from all diabetic patients participating in the study. Different sources of information were used to assess the presence of cardiovascular disease: firstly, a detailed survey on patient medical history, physical examination and complementary investigations were carried out in the patients participating in the study; secondly, medical records from hospitals or other specialists in cases of hospitalisation or out-patient consultation were recorded respectively; thirdly, clinical signs and symptoms referred by the patients to the physicians were registered. The confidentiality and security of the data collected in this study was carried out in accordance with the Spanish law normative in use.

Coronary heart disease was diagnosed when a history of myocardial infarction or angina was reported. Any episode of stroke and intermittent claudication was registered. Angina and intermittent claudication were defined by the WHO criteria of symptoms including precipitating and relieving factors [17]. Family history of diabetes and gestational diabetes was registered. The usual physical activity of most patients was assessed as sedentary (rarely exercises), and active (if the patient did three or more hours of exercise per week). Overweight and obesity were defined as a BMI of 25 to 29 and 30 or over, respectively. Smoking was classified as non-smoker, habitual smoker and former smoker.

Blood pressure was measured after the patient had rested for at least $2 \mathrm{~min}$. It was measured in the arm with a mercury sphygmomanometer and auscultation without masking the readings, usually with a regular size inflatable cuff, unless the arm circumference was greater than $33 \mathrm{~cm}$ for which a large cuff was used. The diastolic pressure was taken at the Korotkoff phase 5. Hypertension was defined if either the pa-

Table 1. Comparison between the study sample and the population of the Basque Country. Distribution by age and sex

\begin{tabular}{|c|c|c|c|c|c|c|}
\hline \multirow[t]{2}{*}{ Age groups } & \multicolumn{3}{|c|}{ Primary Care Sentinel Network sample } & \multicolumn{3}{|c|}{ Basque Country population } \\
\hline & $\begin{array}{l}\text { Men } \\
n(\%)\end{array}$ & $\begin{array}{l}\text { Women } \\
n(\%)\end{array}$ & $\begin{array}{l}\text { Total } \\
n(\%)\end{array}$ & $\begin{array}{l}\text { Men } \\
n(\%)\end{array}$ & $\begin{array}{l}\text { Women } \\
n(\%)\end{array}$ & $\begin{array}{l}\text { Total } \\
n(\%)\end{array}$ \\
\hline $25-44$ years & $15,315(48.0)^{*}$ & $15,155(44.3)^{*}$ & $30,470(46.4)^{*}$ & $349,695(45.2)^{*}$ & $345,511(41.8)^{*}$ & $695,206(43.4)^{*}$ \\
\hline 45-64 years & $9746(30.6)^{*}$ & $9562(28.8) *$ & $19,308(29.4) *$ & $257,401(33.2) *$ & $256,876(31.1) *$ & $514,277(32.1)^{*}$ \\
\hline $65-74$ years & $4236(13.3)$ & $4648(13.4)$ & $8884(13.5)$ & $106,488(13.8)$ & $118,261(14.3)$ & $224,749(14.0)$ \\
\hline Total & $31,887(100)$ & $33,764(100)$ & $65,651(100)$ & $774,405(100)$ & $827,060(100)$ & $1,601,465(100)$ \\
\hline
\end{tabular}

$* p<0.01$ 
tient was on antihypertensive drugs or the blood pressure was equal or over $135 \mathrm{mmHg}$ systolic and/or equal to or over $80 \mathrm{mmHg}$ diastolic [18]. Assessment of macrovascular disease included a routine 12-lead ECG. Peripheral vascular disease was assessed by dorsal pedis and posterior tibial pulses palpation, two or more absent pulses on either side being taken as abnormal. The ankle/wrist index was measured considering less than 1 as abnormal, and the presence of amputations was registered.

Retinopathy was studied with direct ophthalmoscopy carried out by an ophthalmologist and classified as normal, nonproliferative retinopathy, proliferative retinopathy and maculopathy. Nephropathy was defined as albumin urine excretion above $20 \mathrm{mg} / 1$ or above $30 \mathrm{mg} / 24 \mathrm{~h}$. Peripheral neuropathy was assessed by clinical examination with 5.07 monofilament (10 g), and by clinical symptoms, and the presence of ulcers or feet deformations [19]. A fasting blood sample was taken or, when fasting glucose values were between $6.1-7.0 \mathrm{mmol} / \mathrm{l}$ (110 to $126 \mathrm{mg} / \mathrm{dl}$ ), an OGTT with $75 \mathrm{~g}$ of glucose load was carried out. Analysis of $\mathrm{HbA}_{1 \mathrm{c}}$ was done using chromatography (HPLC) (range for normal values between 4.8-6.2\%). Plasma total cholesterol, HDL, LDL and triglycerides concentrations were measured. We used the Third Report of the National Cholesterol Education Program (NCEP) recommended target values of total cholesterol of less than $5.17 \mathrm{mmol} / \mathrm{l}$ (200 mg/dl), HDL over $1.03 \mathrm{mmol} / \mathrm{l}$ (40 mg/dl), triglycerides less than $1.68 \mathrm{mmol} / \mathrm{l}(150 \mathrm{mg} / \mathrm{dl})$, and LDL less than $2.58 \mathrm{mmol} / \mathrm{l}(100 \mathrm{mg} / \mathrm{dl})$ [20].

Additionally, the risk of CHD was calculated using the criteria of the Second Joint Task Force of European and other Societies on Coronary Prevention [9]. This level of risk was calculated in diabetic patients without cardiovascular disease, with a multifactorial risk assessment using a combination of risk factors: age, sex, systolic blood pressure in $\mathrm{mmHg}$, total cholesterol concentration, and smoking status. The level of a person's absolute 10-year risk of CHD event was defined as: low under $5 \%$, mild 5 to $10 \%$, moderate 10 to $20 \%$, high 20 to $40 \%$, and very high over $40 \%$.

Statistical analyses: data were analysed using the Statistical Package for the Social Sciences 10.0 for Windows (SPSS, Chicago, Ill., USA). Data was presented as cases per 1000 subjects, percentage and means \pm standard error (SE). Prevalence and incidence were adjusted by age and sex distribution of the Basque population. The following age stratification was selected: 25 to 64 years, 65 to 74 years and older than 74 years. The chi-square $\left(\chi^{2}\right)$ test and Student's $t$ test were applied to compare proportions and means respectively. A $p$ value of less than 0.05 was considered to be statistically significant. When appropriate, data were stratified by age and sex and Mantel Haenszel odds ratio was provided.

\section{Results}

Prevalence During the study period a total of 2920 known Type 2 diabetic patients were recorded. The adjusted prevalence of known Type 2 diabetes was 4.6\% (CI 95\%: 4.5-4.7). The highest prevalence was $12.6 \%$ in the Basque Country population of 65- to 74year-old subjects. Mean age of patients was 68 years, women being older than men $(p<0.001)$. The mean and SE time of diabetes development was $8.1 \pm 0.1$ years (Table 2).

The most frequent complication in known Type 2 diabetic patients was macroangiopathy (33\%), with $30 \%$ having abnormal ECG, $12.4 \%$ CHD, 9.8\% stroke, $14.1 \%$ signs of peripheral vascular disease,

Table 2. Prevalence and annual cumulative incidence of known Type 2 diabetes in Basque Country population

\begin{tabular}{|c|c|c|c|c|c|c|c|}
\hline Prevalent cases & $\begin{array}{l}\text { Men } \\
n=1404\end{array}$ & & $\begin{array}{l}\text { Women } \\
n=1516\end{array}$ & & $\begin{array}{l}\text { Total } \\
n=2920\end{array}$ & & $\mathrm{P}$ value \\
\hline Age $($ mean \pm SE) & $65 \pm 0.3$ & & $69 \pm 0.3$ & & $68 \pm 0.2$ & & $<0.05$ \\
\hline Age group & Cases & Prevalence $\%$ & Cases & Prevalence $\%$ & Cases & Prevalence $\%$ & \\
\hline $25-44$ & 44 & 0.3 & 35 & 0.2 & 79 & 0.3 & \\
\hline$\geq 75$ & 306 & 12.3 & 504 & 11.8 & 810 & 12.0 & \\
\hline Total* & 1404 & 4.6 & 1516 & 4.7 & 2920 & 4.6 & \\
\hline Newly diagnosed cases & $\begin{array}{l}\text { Men } \\
n=140\end{array}$ & & $\begin{array}{l}\text { Women } \\
n=145\end{array}$ & & $\begin{array}{l}\text { Total } \\
n=285\end{array}$ & & $\mathrm{P}$ value \\
\hline $25-44$ & 9 & 0.6 & 7 & 0.5 & 16 & 0.5 & \\
\hline $45-64$ & 67 & 7.3 & 54 & 5.9 & 121 & 6.6 & \\
\hline $65-74$ & 45 & 12.2 & 54 & 13.3 & 99 & 12.8 & \\
\hline$\geq 75$ & 19 & 8.4 & 30 & 7.7 & 49 & 8.0 & \\
\hline Total* & 140 & 5.0 & 145 & 4.9 & 285 & 5.0 & \\
\hline
\end{tabular}

\footnotetext{
* Standardized by age and sex
} 
Table 3. Chronic complications of Type 2 diabetes by sex stratified by age (\%)

\begin{tabular}{|c|c|c|c|c|c|}
\hline $\begin{array}{l}\text { Prevalent cases } \\
\text { Age }\end{array}$ & Sex & $\begin{array}{l}\text { Retinopathy } \\
n=1985\end{array}$ & $\begin{array}{l}\text { Nephropathy } \\
n=2294\end{array}$ & $\begin{array}{l}\text { Neuropathy } \\
n=2540\end{array}$ & $\begin{array}{l}\text { Macroangiopathy } \\
n=2769\end{array}$ \\
\hline $25-64$ & $\begin{array}{l}\text { Male } \\
\text { Female }\end{array}$ & $\begin{array}{l}13 \\
15\end{array}$ & $\begin{array}{l}25 \\
13\end{array}$ & $\begin{array}{r}14 \\
9\end{array}$ & $\begin{array}{l}24 \\
16\end{array}$ \\
\hline $65-74$ & $\begin{array}{l}\text { Male } \\
\text { Female }\end{array}$ & $\begin{array}{l}19 \\
22\end{array}$ & $\begin{array}{l}29 \\
17\end{array}$ & $\begin{array}{l}17 \\
20\end{array}$ & $\begin{array}{l}42 \\
27\end{array}$ \\
\hline \multirow[t]{2}{*}{$75+$} & $\begin{array}{l}\text { Male } \\
\text { Female }\end{array}$ & $\begin{array}{l}22 \\
29\end{array}$ & $\begin{array}{l}37 \\
22\end{array}$ & $\begin{array}{l}30 \\
26\end{array}$ & $\begin{array}{l}52 \\
39\end{array}$ \\
\hline & Total & $\begin{array}{l}20 \\
\mathrm{OR}(\mathrm{MH})=0.8 \\
\text { CI } 95 \%=0.6-1.0\end{array}$ & $\begin{array}{l}23 \\
\text { OR(MH) }=2.1 \\
\text { CI } 95 \%=1.5-3.4\end{array}$ & $\begin{array}{l}19 \\
\text { OR(MH) }=1.1 \\
\text { CI } 95 \%=0.9-1.4\end{array}$ & $\begin{array}{l}33 \\
\text { OR(MH) }=1.7 \\
\text { CI } 95 \%=1.5-2.1\end{array}$ \\
\hline \multicolumn{2}{|c|}{ Newly diagnosed cases } & $\begin{array}{l}\text { Retinopathy } \\
n=173\end{array}$ & $\begin{array}{l}\text { Nephropathy } \\
n=190\end{array}$ & $\begin{array}{l}\text { Neuropathy } \\
n=254\end{array}$ & $\begin{array}{l}\text { Macroangiopathy } \\
n=278\end{array}$ \\
\hline $25-64$ & $\begin{array}{l}\text { Male } \\
\text { Female }\end{array}$ & $\begin{array}{l}5 \\
6\end{array}$ & $\begin{array}{l}6 \\
7\end{array}$ & $\begin{array}{r}11 \\
2\end{array}$ & $\begin{array}{r}17 \\
9\end{array}$ \\
\hline $65-74$ & $\begin{array}{l}\text { Male } \\
\text { Female }\end{array}$ & $\begin{array}{r}9 \\
16\end{array}$ & $\begin{array}{l}36 \\
16\end{array}$ & $\begin{array}{r}5 \\
16\end{array}$ & $\begin{array}{l}35 \\
17\end{array}$ \\
\hline \multirow[t]{2}{*}{$75+$} & $\begin{array}{l}\text { Male } \\
\text { Female }\end{array}$ & $\begin{array}{l}0 \\
0\end{array}$ & $\begin{array}{r}13 \\
6\end{array}$ & $\begin{array}{l}39 \\
25\end{array}$ & $\begin{array}{l}47 \\
30\end{array}$ \\
\hline & Total & $\begin{array}{l}6 \\
\text { OR }(\mathrm{MH})=0.6 \\
\text { CI } 95 \%=0.1-2.6\end{array}$ & $\begin{array}{l}12 \\
\text { OR(MH) }=1.6 \\
\text { CI } 95 \%=0.6-4.3\end{array}$ & $\begin{array}{l}12 \\
\text { OR(MH) }=1.4 \\
\text { CI } 95 \%=0.6-3.2\end{array}$ & $\begin{array}{l}22 \\
\mathrm{OR}(\mathrm{MH})=2.3 \\
\text { CI } 95 \%=1.2-4.6\end{array}$ \\
\hline
\end{tabular}

OR (MH): Odds Ratio of Mantel-Haenszel standardized by age

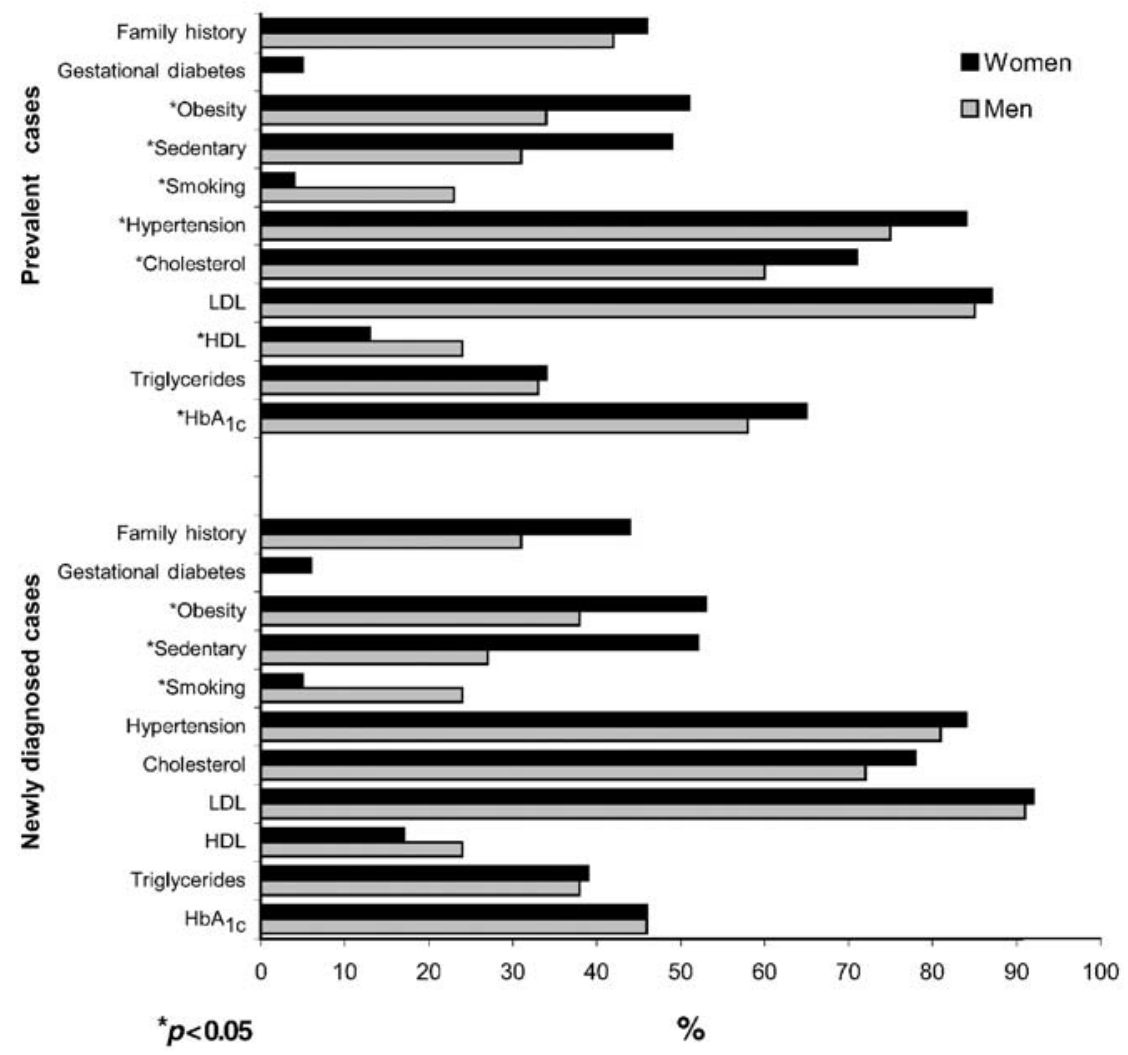

Fig. 1. Cardiovascular risk factors $(\%)$ standardised by age in prevalent and newly diagnosed cases in known Type 2 diabetes: Total cholesterol $\geq 5.17 \mathrm{mmol} / \mathrm{l}$ (200 mg/dl), HDL

$<1.03 \mathrm{mmol} / \mathrm{l} \quad(40 \mathrm{mg} / \mathrm{dl})$, Triglycerides $\geq 1.68 \mathrm{mmol} / \mathrm{l}$ $(150 \mathrm{mg} / \mathrm{dl}), \quad \mathrm{LDL} \geq 2.58 \mathrm{mmol} / \mathrm{l}(100 \mathrm{mg} / \mathrm{dl})$ and $\mathrm{HbA}_{1 \mathrm{c}}$ $\geq 6.5 \%$ ) 
Table 4. Cardiovascular risk factors in known Type 2 diabetes standardised by age

\begin{tabular}{|c|c|c|c|c|}
\hline Prevalent cases & $\begin{array}{l}\text { Men } \\
n=1332\end{array}$ & $\begin{array}{l}\text { Women } \\
n=1442\end{array}$ & $\begin{array}{l}\text { Total } \\
n=2774\end{array}$ & $p$ value \\
\hline $\begin{array}{l}\text { Familiar history of diabetes (\%) } \\
\text { Gestational diabetes }(\%)\end{array}$ & 42 & $\begin{array}{r}46 \\
5\end{array}$ & 44 & NS \\
\hline $\begin{array}{l}\text { Physical activity }(\%) \text { : } \\
\text { active } \\
\text { sedentary }\end{array}$ & $\begin{array}{l}69 \\
31\end{array}$ & $\begin{array}{l}51 \\
49\end{array}$ & $\begin{array}{l}58 \\
42\end{array}$ & $<0.001$ \\
\hline $\begin{array}{l}\text { Smoking }(\%) \text { : } \\
\text { never } \\
\text { former } \\
\text { current }\end{array}$ & $\begin{array}{c}38 \\
39 \\
23 \\
\text { Means } \pm \mathrm{SE}\end{array}$ & $\begin{array}{c}93 \\
3 \\
4 \\
\text { Means } \pm \mathrm{SE}\end{array}$ & $\begin{array}{c}67 \\
20 \\
13 \\
\text { Means } \pm \text { SE }\end{array}$ & $<0.001$ \\
\hline $\begin{array}{l}\text { Total cholesterol } \\
(\mathrm{mmol} / \mathrm{l}) \\
(\mathrm{mg} / \mathrm{dl})\end{array}$ & $\begin{array}{l}5.43 \pm 0.02 \\
210 \pm 1.1\end{array}$ & $\begin{array}{l}5.69 \pm 0.02 \\
220 \pm 1.0\end{array}$ & $\begin{array}{l}5.56 \pm 0.02 \\
215 \pm 0.8\end{array}$ & $<0.001$ \\
\hline $\begin{array}{l}\text { LDL } \\
(\mathrm{mmol} / \mathrm{l}) \\
(\mathrm{mg} / \mathrm{dl})\end{array}$ & $\begin{array}{c}3.46 \pm 0.02 \\
134 \pm 1.1\end{array}$ & $\begin{array}{l}3.56 \pm 0.02 \\
138 \pm 1.1\end{array}$ & $\begin{array}{l}3.51 \pm 0.02 \\
136 \pm 0.8\end{array}$ & $<0.05$ \\
\hline $\begin{array}{l}\text { HDL } \\
(\mathrm{mmol} / \mathrm{l}) \\
(\mathrm{mg} / \mathrm{dl})\end{array}$ & $\begin{array}{c}1.31 \pm 0.01 \\
51 \pm 0.5\end{array}$ & $\begin{array}{l}1.45 \pm 0.01 \\
56 \pm 0.4\end{array}$ & $\begin{array}{l}1.37 \pm 0.01 \\
53 \pm 0.4\end{array}$ & $<0.001$ \\
\hline
\end{tabular}

$8.4 \%$ intermittent claudication, and $1.4 \%$ amputations. Diabetic nephropathy (microalbumiuria) was present in $23 \%$, retinopathy in $20 \%$ (46\% non-proliferative, $17 \%$ proliferative, $15 \%$ maculopathy and $22 \%$ nonspecified retinopathy), and neuropathy in $19 \%$ of the patients. Total large vessel disease $(\mathrm{OR}=1.7$, CI 95\% $1.5-2.1)$ and nephropathy (OR=2.1, CI 95\% $1.5-3.4)$ in men exceeded that in women (Table 3).

Data of cardiovascular risk factors in prevalent cases are described in Table 4. Of the prevalent cases $61 \%$ had $\mathrm{HbA}_{1 \mathrm{c}} 6.5 \%$ or over, being higher in women $(64.8 \%)$ than in men $(57.6 \%)(p<0.05)$. Of the Type 2 diabetic patients, $85 \%$ had $\mathrm{LDL} \geq 2.58 \mathrm{mmol} / 1,65.4 \%$ total cholesterol $\geq 5.17 \mathrm{mmol} / \mathrm{l}, 18.3 \%$ HDL less than $1.03 \mathrm{mmol} / \mathrm{l}$ and $33.4 \%$ triglycerides over $1.68 \mathrm{mmol} / \mathrm{l}$. Abnormal concentrations of HDL were higher and total cholesterol lower in men $(24.1 \%$ and $59.7 \%$ respectively) than in women ( $13.1 \%$ and $70.6 \%$ respectively) $(p<0.05)$. High BP was found in $79.6 \%$ of the patients, and was higher in women $(84.1 \%)$ than men $(74.6 \%)$ $(p<0.05)$. Obesity was found in $42.4 \%$ of the patients being higher in women $(50.7 \%)$ than in men $(33.6 \%)$ $(p<0.05)$. Only $16 \%$ of Type 2 diabetic patients had normal weight and $84 \%$ were overweight or obese. A sedentary lifestyle was more frequent in women $(48.6 \%)$ than in men $(31.3 \%) \quad(p<0.05)$. However, smoking was significantly more frequent among men than women $(p<0.05)$ (Fig. 1).

The value of $\mathrm{HbA}_{1 \mathrm{c}}$ and the duration of diabetes were associated with higher frequency of complications.

The risk of CHD in known Type 2 diabetic patients was higher in men than in women. Of the diabetic men $60 \%$ showed high $(20-40 \%)$ or very high $(>40 \%)$ risk of $\mathrm{CHD}$, while $56 \%$ of the women had values compatible with moderate (10-20\%), mild (5-10\%) or low $(<5 \%)$ risk of CHD $(p<0.05)$ (Table 5$)$.

Incidence. The annual standardised cumulative incidence of known Type 2 diabetes in the Basque Country population older than 24 years of age attending the primary care centers was 5 per 1000 inhabitants (CI 95\%: 4.9-5.1) with similar incidence in both sexes. 
Table 4. (continued)

\begin{tabular}{|c|c|c|c|c|}
\hline Newly diagnosed cases & $\begin{array}{l}\text { Men } \\
n=138\end{array}$ & $\begin{array}{l}\text { Women } \\
n=140\end{array}$ & $\begin{array}{l}\text { Total } \\
n=278\end{array}$ & $p$ value \\
\hline $\begin{array}{l}\text { Familiar history of diabetes }(\%) \\
\text { Gestational diabetes }(\%)\end{array}$ & 31 & $\begin{array}{r}44 \\
6\end{array}$ & 37 & $\mathrm{NS}$ \\
\hline $\begin{array}{l}\text { Physical activity (\%): } \\
\text { active } \\
\text { sedentary }\end{array}$ & $\begin{array}{l}73 \\
27\end{array}$ & $\begin{array}{l}49 \\
51\end{array}$ & $\begin{array}{l}60 \\
40\end{array}$ & $<0.001$ \\
\hline $\begin{array}{l}\text { Smoking }(\%) \text { : } \\
\text { never } \\
\text { former } \\
\text { current }\end{array}$ & $\begin{array}{c}41 \\
35 \\
24 \\
\text { Means } \pm \text { SE }\end{array}$ & $\begin{array}{r}91 \\
4 \\
5 \\
\text { Means } \pm \text { SE }\end{array}$ & $\begin{array}{c}67 \\
19 \\
14 \\
\text { Means } \pm \text { SE }\end{array}$ & $<0.001$ \\
\hline BMI: & $29 \pm 0.4$ & $32 \pm 0.6$ & $31 \pm 0.4$ & $<0.001$ \\
\hline $\begin{array}{l}\text { Total cholesterol } \\
(\mathrm{mmol} / \mathrm{l}) \\
(\mathrm{mg} / \mathrm{dl})\end{array}$ & $\begin{array}{r}5.74 \pm 0.1 \\
222 \pm 3.8\end{array}$ & $\begin{array}{r}5.89 \pm 0.1 \\
228 \pm 3.6\end{array}$ & $\begin{array}{l}5.81 \pm 0.07 \\
225 \pm 2.6\end{array}$ & NS \\
\hline $\begin{array}{l}\text { LDL } \\
(\mathrm{mmol} / \mathrm{l}) \\
(\mathrm{mg} / \mathrm{dl})\end{array}$ & $\begin{array}{c}3.69 \pm 0.09 \\
143 \pm 3.6\end{array}$ & $\begin{array}{c}3.74 \pm 0.09 \\
145 \pm 3.4\end{array}$ & $\begin{array}{c}3.72 \pm 0.06 \\
144 \pm 2.5\end{array}$ & NS \\
\hline $\begin{array}{l}\text { HDL } \\
(\mathrm{mmol} / \mathrm{l}) \\
(\mathrm{mg} / \mathrm{dl})\end{array}$ & $\begin{array}{l}1.31 \pm 0.03 \\
51 \pm 1.4\end{array}$ & $\begin{array}{l}1.37 \pm 0.03 \\
53 \pm 1.2\end{array}$ & $\begin{array}{l}1.34 \pm 0.02 \\
52 \pm 1.0\end{array}$ & NS \\
\hline
\end{tabular}

Table 5. CHD risk level in known Type 2 diabetes* (\%)

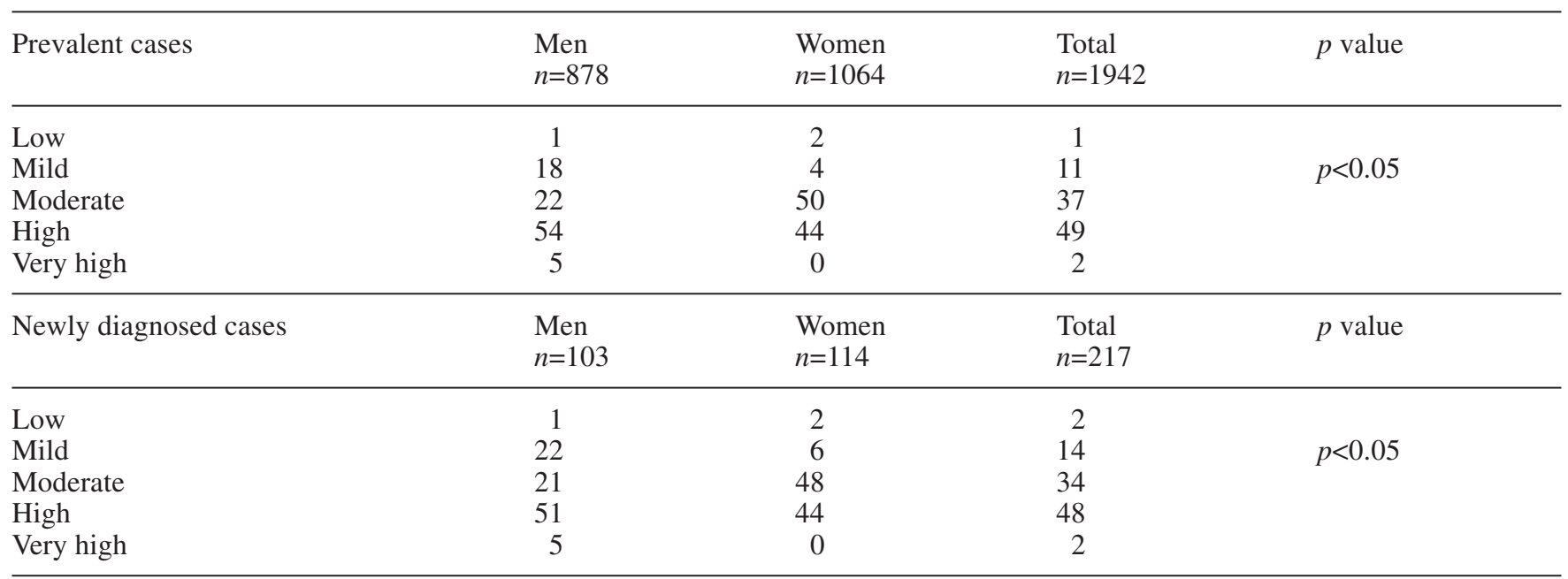

* in diabetic patients without cardiovascular disease 
Incidence peak was found in the 65- to 74-year-old group (12.8 per 1000$)$. The average age of the newly diagnosed Type 2 diabetes cases was $64 \pm 0.7$ years, higher in women than in men $(p<0.05)$ (Table 2). Of the patients $86 \%$ were diagnosed by fasting glucose, $4.6 \%$ by random glucose and $8.5 \%$ by OGTT. Thirtysix per cent of the 285 newly diagnosed Type 2 diabetic patients already had one or more complications at diagnosis. Macroangiopathy was the most frequent complication affecting $22 \%$ of the patients; abnormal ECG was present in 7\%, CHD (7\%), stroke (4\%), intermittent claudication (3\%), signs of peripheral arteriopathy (14\%), and amputations (1\%). Neuropathy was present in $12.5 \%$ of the patients, nephropathy in $12.6 \%$, and retinopathy in $6.5 \%$ (Table 3 ). The prevalence of macrovascular disease is higher in newly diagnosed Type 2 diabetic men than in women $(\mathrm{OR}=2.3$, CI 95\%: 1.2-4.6).

Data on cardiovascular risk factors is described in Table 4. Forty-six per cent of the newly diagnosed patients had $\mathrm{HbA}_{1 \mathrm{c}}$ values of $6.5 \%$ or over. More than $70 \%$ of these patients had total cholesterol $\geq 5.17 \mathrm{mmol} / 1,91 \%$ LDL $\geq 2.58 \mathrm{mmol} / \mathrm{l}, 20.8 \% \mathrm{HDL}$ less than $1.03 \mathrm{mmol} / \mathrm{l}$, and $38.8 \%$ triglycerides $\geq 1.68 \mathrm{mmol} / \mathrm{l}$. High BP was found in $83.2 \%$ of newly diagnosed Type 2 diabetic patients, $85 \%$ in women and $81.4 \%$ in men (NS). Obesity was present in $45.6 \%$ of the patients and $87.2 \%$ were overweight or obese. Obesity was more frequent in women $(53.0 \%)$ than in men $(38.4 \%)(p<0.05)$ as was sedentary lifestyle $(52 \%$ vs $27 \%)(p<0.05)$. However smoking was significantly more frequent among men than women $(p<0.05)$ (Fig. 1).

The risk of CHD for newly diagnosed cases was higher in men than in women. More than half of the men $(56 \%)$ showed high $(20-40 \%)$ or very high CHD risk $(>40 \%)$, while $56 \%$ of the women had values compatible with moderate (10-20\%), mild (5-10\%) or low risk of CHD $(<5 \%)(p<0.05)$ (Table 5).

\section{Discussion}

Prevalence and incidence of known Type 2 diabetes. Sentinel networks are an epidemiological information system and have been greatly developed in the last few years [21]. Many sentinel networks in Europe [22, 23, 24, 25] and in the United States [12] have been used to study diseases diagnosed at the primary care level. The usefulness of these networks has been confirmed both for the study of acute and chronic pathologies, including diabetes [26, 27, 28, 29, 30, 31]. One of the limitations attributed to the sentinel system is its ability to represent accurately because of the voluntary participation of the physicians in the network. However, several studies have validated the information gathered through sentinel networks and it has been concluded that such networks are feasible and have a low-biased approach for population studies [28]. Other studies have concluded that sentinel samples are representative in age and sex distribution of the total practice population when they are based on an adequate size [32]. Likewise, those studies that have compared the Ambulatory Sentinel Practice Network (ASPN) sample with the random National Ambulatory Medical Care Survey (NAMCS) in the United States, have concluded, that the ASPN sample is sufficiently representative of the general population and that Sentinel Network serves as a useful laboratory for investigation in primary care $[33,34]$. Although study samples based on sentinel networks have some limitations, given the characteristics of our sample, we consider that the results of this study could be biased a little and therefore, the extrapolation of results to the general population of the Basque Country is possible.

There is no current national epidemiological diabetes data in Spain. Type 2 diabetes epidemiological information in our country has been carried out in small population areas and with different methodologies [35, 36, 37, 38, 39, 40, 41, 42, 43, 44, 45, 46, 47]; therefore, the comparisons among these data should be considered carefully. These studies have shown the prevalence of Type 2 diabetes between $4.0 \%$ [37] and $18 \%$ [46]. Only four cross-sectional studies provide prevalence data at the regional level. The total prevalence of Type 2 diabetes (known and unknown), in Aragón (1994) was 6.1\% [38], in Galicia (1995) 7.8\% [43], Cataluña (1999) 10.3\% [44] and Asturias 9.9\% [47], The prevalence of known Type 2 diabetes in our study was $4.6 \%$ (CI 4.5-4.7) compared to $3 \%$ in Aragón, $6.7 \%$ in Cataluña and $4 \%$ in Asturias. These data are in agreement with the prevalence of diabetes described in several European countries, 3.2\% Ireland, 4.1\% Belgium, 4.2\% Germany, 3.5\% United Kingdom, $4.0 \%$ France or $7.1 \%$ in Italy [8]. However, our prevalence data is lower than the United States data with a $7.3 \%$ of known diabetes in the year 2000 [48].

There is very little data on the incidence of Type 2 diabetes in Spain and Europe. In a 10-year prospective study with a sample of 584 patients older than 30 years of age in Leioa (Basque Country), an annual incidence of known Type 2 diabetes of 4.1 per 1000 was estimated [45]. The Cremona Study in Italy found a diabetes incidence of 2.1 per 1000 person-years [49]. In our study we found an annual incidence of 5 per 1000 (CI 95\%: 4.9-5.1), with a peak incidence between 65 to 74 year age group (12.8 per 1000). Our annual incidence for the 45 to 64 age group was similar to that estimated for the United States $(6.03$ per 1000) [50]. In Italy the incidence was 6.0 per 1000 person-year in people older than 50 years of age [49].

Chronic complications. We found a prevalence of retinopathy, nephropathy and polineuropathy around 20\% in known Type 2 diabetes. Macroangiopathy was the most common complication present in $33 \%$ of known 
Type 2 diabetic patients. The prevalence of Type 2 diabetic complications in our study is similar to that described previously in Spain in the last decade [51, 52, $53,54,55,56,57,58,59,60,61,62]$, and in the WHO Multinational Study of Vascular Disease in Diabetes (WHO MSVDD) [63]. However, in a recent study in China, the prevalence of microvascular complications was higher and the prevalence of macrovascular disease was lower than in the previous studies [64]. The high rates of retinopathy (47\%) and proteinuria $(57 \%)$ found in China could be related to later diagnosis, degree of hyperglycaemia, and/or increased susceptibility to microangiopathy. The low prevalence of cardiovascular risk factors is a likely contributor to the low rates of arterial disease $(<20 \%)$ in the Chinese diabetic cohort, and resembles the Tokyo and Hong Kong centres of the WHO MSVDD [63, 64]. In our study, total large vessel disease and nephropathy in men exceeded that in women. However in the WHO MSVDD [63] and in the Chinese sample [64] the prevalence of macroangiopathy was higher in women than in men. The higher CHD risk that we have found in Type 2 diabetic men is in agreement with the higher prevalence of macroangiopathy found in our Type 2 diabetic men.

There are very few studies on long-term complications in incidence cases of Type 2 diabetes. Thirty-six (36\%) of the newly diagnosed Type 2 diabetic patients already have one or more complications at diagnosis in our study. In the UKPDS half of the newly diagnosed Type 2 diabetic patients have complications at diagnosis [65]. This difference is mainly due to the lower prevalence in retinopathy in our patients, $6.5 \%$, compared to $25 \%$ in the UKPDS. This high rate could be explained by the later diagnosis of diabetes in the UKPDS that could be suspected by the value of $\mathrm{HbA}_{1 \mathrm{c}}$ of $11.6 \%$ found in their patients at diagnosis compared with $\mathrm{HbA}_{1 \mathrm{c}}$ of $6.8 \%$ in our study. However, in our study, the validity of retinopathy diagnosed by different ophthalmologists in practice is a possible limitation. Macrovascular disease was again the most frequent complication in our study, with $22 \%$ of the newly diagnosed Type 2 diabetic patients having CHD, stroke or peripheral vascular disease. In Finland, which has a high prevalence of CHD in the general population, newly diagnosed diabetic patients had an $18 \%$ prevalence of myocardial infarction in both sexes, and if angina and abnormal ECG were included, $32 \%$ of the men and $42 \%$ of the women had CHD, which was higher than in the control population [66]. In our study, the prevalence of macrovascular disease is higher in newly diagnosed Type 2 diabetic men than in women, contrary to the higher prevalence of abnormal ECG and the absence of foot pulses in women than in men in UKPDS [65]. This higher frequency of macroangiopathy that we have found is in agreement with the high CHD risk level present in our newly diagnosed Type 2 diabetic men. In our sample, as in
UKPDS, newly diagnosed Type 2 diabetic women have a similar prevalence of microvascular complications to men.

Cardiovascular risk factors. Data from UKPDS [65] suggest that each particular macrovascular complication could be dependent on several specific and different cardiovascular risk factors in Type 2 diabetic patients. The correlation found is similar to those in nondiabetic patients, including stroke with hypertension [67], peripheral vascular disease with smoking [68], and a low HDL cholesterol, hypertriglyceridemia and hypercholesterolemia with heart disease $[69,70]$. The association of cardiovascular risk factors to known Type 2 diabetic patients in our study is similar to other studies in Spain [37, 38, 51, 52, 54, 55, 56, 62, 71, 72, $73,74]$, and to the WHO SVDD [63]. The lipid profile found in Type 2 diabetic patients are frequently above the recommendations of the third report of the National Education Program (NCEP) and the American Diabetes Association [20,75] for Type 2 diabetic patients.

In newly diagnosed Type 2 diabetes we have found a high prevalence of cardiovascular risk factors. The distribution of cardiovascular risk factors between the sexes is similar to our prevalent cases and to the UKPDS newly diagnosed Type 2 diabetic patients [65].

From the Multiple Risk Factor Intervention Trial (MRFIT) data, it is also evident that diabetes is a strong, independent risk factor for cardiovascular disease (CVD) mortality over and above the effect of BP, serum cholesterol, and cigarette smoking [5]. In our study high $\mathrm{HbA}_{1 \mathrm{c}}$ and duration of diabetes are associated with diabetic complications.

CHD risk level. Type 2 diabetes mellitus is characterized by an increased risk of CVD in men and women [76]. In particular there is an excess incidence of CHD and stroke in people with diabetes [5, 77]. In the last decade or so, several prospective studies have examined the strength of the associations between various putative risk factors and CVD mortality in diabetic patients. The three largest studies MRFIT, UKPDS and WHO MSVDD [5, 7, 78] have shown that classic CVD risk factors like high $\mathrm{BP}$, serum cholesterol and cigarette smoking are predictive of CVD mortality in patients with Type 2 diabetes. Furthermore, the studies mentioned above confirm that the presence of a combination of these classic CVD risk factors markedly increase CVD mortality in men and woman with Type 2 diabetes. Traditionally, risk-factor guidelines have been concerned with unifactorial assessment in the management of hypertension, hyperlipidaemia or diabetes. This has resulted in undue emphasis being placed on individually high risk factors rather than on the overall level of risk based on a combination of risk factors. Therefore, we have used the joint recommendations of the Task Force Report for prevention of CHD in clinical practice emphasizing the importance 
of multifactorial risk assessment to measuring global risk of CHD in a Type 2 diabetic population [9]. Sixty percent of our Type 2 diabetic men and around 50 percent of our Type 2 diabetic women, without previously cardiovascular diseases, have high or very high risk of CHD. Diabetic patients without previous myocardial infarction have as high a risk of myocardial infarction as non-diabetic patients with previous myocardial infarction, suggesting that Type 2 diabetes could confer the same degree of risk as pre-existing coronary heart disease [6]. However, in a recent crosssectional and cohort study the authors had found that patients with Type 2 diabetes were at a lower risk of cardiovascular outcomes than patients with established coronary heart disease [79]. This seems more likely because patients with previous cardiovascular diseases are already at a very high absolute risk of a further vascular event [9]. In our study about half of the patients had a high or very high CHD risk. Therefore, Type 2 diabetic patients without a previous history of cardiovascular diseases have a different CHD risk according to the simultaneous combination of cardiovascular risk factors. Our results have important implications for clinical management and control practices because those at the highest multi-factorial risk can be identified and targeted for lifestyle interventions, and selective use of proven drug therapies.

National Health Systems must be aware of the increase in the incidence and prevalence of Type 2 diabetes, and its implications for the health of the general population. Type 2 diabetes is associated with potentially avoidable chronic complications and cardiovascular risk factors generating a high risk of CHD. Treatment of Type 2 diabetes must aim not only improving blood glucose control, but also eliminating cardiovascular risk factors. Moreover, it adds to the growing consensus that the best possible management of diabetes, based on a multifactorial approach, represents good preventive medicine. Primary care practitioners, in the front line of the Health Care System, should provide an integrated and multi-intensive treatment that will be essential for preventing chronic complications and reducing the high CHD risk of Type 2 diabetic patients.

Acknowledgements. List of investigators and members of the Basque Country Sentinel Practice Surveillance Network.

Álava: R. Abasolo, I. Aguirrezabal, M. Arroniz. ME. Azpeitia, J. de Castro, R. Esquisabel, M.I. Etxebarria, D. Gonzalo, R. Gracia, J.M. Hernández de Pedro, M.A. Larrañaga, F.J. Nafarrate, J.M. Ordoño, J. Pérez de Viñaspre, F. Ricarte.

Bizkaia: V. González, M. Maortua, L. Unzueta, P. Valdés, J.C. de la Fuente, E. Etxegarai, V. Astobiza, F.J. Eizaguirre, E. Elorriaga, M.P. Ruiz, F. Aizpurua, C. Ugarte, M.D. García, M.L. Rodríguez, A. Bolaños, M.A. Azazeta, A. Berganza, P. Zaballa, I. Elizarán, J.I. Gorroño, M. Diez, M.F. Loyola, A. Burgui, J. Crespo, J. Rodríguez, M. García, K. Muñiz, M.I. Olabarrieta, E. de la Peña, T. López.

Gipuzkoa: C. Calderón, E. Auzmendi, V. Tapiz, M.A. Arrondo, M. Luke, J.L. Aguirrezabala, J.I. Urgoitia, L. Pérez, I. Andréu,
M.V. González, D. Baixas de Ros, I. Osa, M.L. Vivanco, I. Ibarrondo, M.J. Domaica, P. Aldave.

We are most grateful to M.A. Ga Calabuig, I. Baonza, M. Goiri, I. Lopez, T. Vega and C. Alda for their collaboration with the Basque Country Sentinel Network. We thank S. Esnaola and N. Muniozguren for their critical reading of the manuscript and we also thank I. Arteagoitia for linguistic comments in the preparation of the paper.

\section{References}

1. Javitt JC, Yen-Pin Chiang YP (1995) Economic Impact of Diabetes. In: Harris MI, Cowie CC, Stern MP, Boyko EJ, Reiber GE, Bennett PH (eds) Diabetes in America, 2nd edn. National Diabetes Data Group of the National Institute of Diabetes and Digestive and Kidney Diseases, National Institutes of Health, Bethesda, Maryland, pp 601-611

2. American Diabetes Association (1998) Economic consequences of diabetes mellitus in the U.S. in 1997. Diabetes Care 31:296-309

3. Selby JV, Ray GT, Zhang D, Colby CJ (1997) Excess costs of medical care for patients with diabetes in a managed care population. Diabetes Care 20:1396-1402

4. Geiss LS, MA, Herman WH, Smith PJ (1995) Mortality in non-insulin-dependent diabetes. In: Harris MI, Cowie CC, Stern MP, Boyko EJ, Reiber GE, Bennett PH (eds) Diabetes in America, 2nd edn. National Diabetes Data Group of the National Institute of Diabetes and Digestive and Kidney Diseases, National Institutes of Health, Bethesda, Maryland, pp 233-257

5. Stamler J, Vaccaro O, Neaton JD, Wenworth DW (1993) Diabetes, other risk factors, and 12-Yr cardiovascular mortality for men screened in the Multiple Risk Factor Intervention Trial. Diabetes Care 16:434-443

6. Haffner SM, Lehto S, Ronnemaa T, Pyorala K, Laakso M (1998) Mortality from coronary heart disease in subjects with type 2 diabetes and in nondiabetic subjects with and without prior myocardial infarction. N Engl J Med 339:229-234

7. Turner RC, Millns H, Neil HA et al. (1998) Risk factors for coronary artery disease in non-insulin dependent diabetes mellitus: United Kingdom prospective diabetes study (UKPDS: 23). BMJ 316:823-828

8. Cockram C, Alberti G, Allgot B, Aschner P, Dwyer T, Haffner S, Mbanya JC, McLaughlin C, Mohan V (2001) Diabetes and cardiovascular diseases: time to act. Report of the International Diabetes Federation (IDF), Brussels

9. Recommendations of the Second Joint Task Force of European and other Societies on Coronary Prevention (1998) Prevention of coronary heart disease clinical practice. Eur Heart J 19:1434-1503

10. Renders CM, Valk GD, Griffin SJ, Wagner EH, Van Eijk JT, Assendelft WJJ (2001) Interventions to improve the management of diabetes in primary care, outpatient, and community settings. Diabetes Care 24:1821-1833

11. Chauvin P (1994) Constitution and monitoring of an epidemiological surveillance network with sentinel general practitioners. Eur J Epidemiol 10:477-479

12. Green LA, Wood M, Becker L et al. (1984) The Ambulatory Sentinel Practice Network: purpose, methods, and policies. J Fam Pract 18:275-280

13. Van Casteren V, Leurquin P (1992) Eurosentinel: development of an international sentinel network of general practitioners. Methods Inf Med 31:147-152

14. Manuguerra JC, Mosnier A, Paget WJ (2001) Monitoring of influenza in the European network member countries from October to April 2001. Eur Surveill 6:127-133 
15. World Health Organization (1985). Diabetes mellitus: report of a WHO study group. Technical report series 727 . WHO, Geneva

16. Alberti KG, Zimmet PZ for the WHO Consultation (1998) Definition, diagnosis and classification of diabetes mellitus and its complications. Part 1: Diagnosis and classification of diabetes mellitus. Report of a WHO Consultation. Diabet Med 15:539-553

17. Rose GA, Blackburn H, Gillum RF, Prineas RJ (1982) In: World Health Organization (eds) Cardiovascular survey methods. WHO Monograph Series no 56. World Health Organization, Geneva, pp 163-164

18. Joint National Committee (1997) The sixth report of the Joint National Committee on Detection, Evaluation and Treatment of High Blood Pressure. Arch Intern Med 157:2413-2446

19. Mayfield JA, Reibert GE, Sanders LJ, Janisse D, Pogach LM (1998) Preventive foot care in people with diabetes. Diabetes Care 21:2161-2179

20. Third Report of the National Cholesterol Education Program (NCEP) (2001) Expert Panel on detection, evaluation, and treatment of high blood cholesterol in adults. JAMA 285:2486-2497

21. Culpepper L, Froom J (1988) The International Primary Care Network: purpose, methods, and policies. Family Med 20:197-201

22. Chauvin P, Valleron A-J (1998) Participation of French general practitioners in public health surveillance: a multidisciplinary apoproach. J Epidemiol Community Health 52 [Suppl 1]:2S-8S

23. Middelkoop BJ, Bohnen AM, Duisterhout JS, Pleumeekers HJ, Prins A (1994) A computerized network of general practices in Rotterdam, The Netherlands. Am J Public Health 84:1852-1853

24. Matter HC, Cloetta J, Zimmermann H et al. (1995) Measles, mumps and rubella: monitoring in Switzerland through a sentinel network, 1986-1994. J Epidemiol Community Health 49 [Suppl 1]:4-8

25. Capozzi C, Buonomo E, Fusiello S et al. (1997) A sentinel network of general practitioners for epidemiologic surveillance in Italy. Stud Health Technol Inform 43:211-214

26. Fleming DM, Zambon M, Bartelds AI, Jong JC de (1999) The duration and magnitude of influenza epidemics: a study of surveillance data from sentinel general practices in England, Wales and the Netherlands. Eur J Epidemiol 15:467-473

27. Maurice S, Pommereau X, Pueyo S et al. (1989) Epidemiological surveillance of suicides and attempted suicides in Aquitaine, south-west France, using an original computer network of sentinel general practitioners. J Epidemiol Community Health 43:290-292

28. Schlaud M, Seidler A, Salje A et al. (1995) Organochloride residues in human breast milk: analysis through a sentinel practice nerwork. J Epidemiol Community Health 49 [Suppl 1]:17-21

29. Green LA, Hames CG Sr, Nutting PA (1994) Potential of practice-based research networks: experiences from ASPN. Ambulatory Sentinel Practice Network. J Fam Pract 38: 400-406

30. Wens J, Van Casteren V, Vermeire E, Van Royen P, Pas L, Denekens J (2001). Diagnosis and treatment of type 2 diabetes in three Belgian regions. Registration via a network of sentinel general practices. Eur J Epidemiol 17:743-750

31. Ruwaard D, Gijsen R, Bartelds AI, Hirasing RA, Verkleij H, Kromhout D (1996) Is the incidence of diabetes increasing in all age-groups in The Netherlands? Results of the second study in the Dutch Sentinel Practice Network. Diabetes Care 19:214-218
32. Thomas DR, Salmon RL, Westmoreland D, Palmer SR (1998) Surveillance of influenza in Wales: interpreting sentinel general practice rates using contemporaneous laboratory data. Opportunities and limitations. J Epidemiol Community Health 52 [Suppl 1]:28S-31S

33. Green LA, Miller RS, Reed FM, Iverson DC, Barley GE (1993) How representative of typical practice are practicebased research networks? A report from the Ambulatory Sentinel Practice Network Inc (ASPN). Arch Fam Med 2:939-949

34. Nutting PA, Baier M, Werner JJ, Cutter G, Reed FM, Orzano AJ (1999) Practice patterns of family physicians in practice-based research networks: a report from ASPN. Ambulatory Sentinel Pratice Network. J Am Board Fam Pract 12:278-284

35. Bayo J, Sola C, García F, Latorre PM, Vazquez JA (1993) Prevalencia de la diabetes mellitus no dependiente de la insulina en Lejona (Vizcaya). Med Clin (Barc) 101:609612

36. Monclús JF, Álvarez JI. Arasa MJ, Aguilar C, Viñas JJ, Curto C (2001) Los criterios de la ADA-97, la prevalencia de diabetes mellitus y las comarcas más meridionales de Cataluña. Aten Primaria 27:178-182

37. Franch Nadal J, Alvarez Torices JC, Alvarez Guisasola F, Diego Dominguez F, Hernandez Mejia R, Cueto Espinar A (1992) Epidemiología de la diabetes mellitus en la provincia de León. Med Clin (Barc) 98:607-611

38. Tamayo-Marco B, Faure-Nogueras E, Roche-Asensio MJ, Rubio-Calvo E, Sanchez-Oriz E, Salvador-Olivan JA (1997) Prevalence and impaired glucose in Aragón, Spain. Diabetes Care 20:534-536

39. Serna MC, Madrid M, Cruz I, Gasco E, Ribelles M, Serra Li (1999) Estimación de la prevalencia de diabetes mellitus en seis comarcas de la provincia de Lleida. Endocrinología 46:83-86

40. Pallardo Sanchez LF, Ferre C, Puertas L, Pallardo Peinado LF (1980) Prevalencia de diabetes conocida en la población rural española en 1978. Rev Clin Esp 159:243249

41. Calle Pascual AL, Gomez Ballesteros V, Leon Carralafuente E (1988) Prevalencia de diabetes mellitus en la provincia de Guadalajara. Med Clin (Barc) 90:40

42. Vila LL, Subirats E, Vila T, Margalef N, Cardona M, Vallesacar R (1994) Prevalencia de diabetes en la Cerdanya (comarca del Pirineo Oriental). Endocinología 41:305309

43. Muniz J, Hervada J, Juane R, Lopez Rodriguez I, Castro Beiras A (1995) Prevalence of diabetes mellitus in the population aged 40-69 years in Galicia, northwest Spain. Diebetes Res Clin Pract 30:137-142

44. Castell C, Tresserras R, Serra J, Goday A, Lloveras G, Salleras L (1999) Prevalence of diabetes in Catalonia (Spain): an oral glucose tolerance test-based population study. Diabetes Res Clin Pract 43:33-40

45. Vazquez JA, Gaztambide S, Soto-Pedre E (2000) Estudio prospectivo a 10 años sobre la incidencia y factores de riesgo de diabetes mellitus tipo 2. Med Clin (Barc) 115:534-539

46. Pablos-Velasco PL de, Martinez-Martin FJ, RodriguezPerez F, Ania BJ, Losada A, Betancor P (2001) The Guia Study. Prevalence and determinants of diabetes mellitus and glucose intolerance in a Canarian Caucasian population-comparison of the 1997 ADA and the 1985 WHO criteria. The Guia Study. Diabet Med 18:235-241

47. Botas P, Delgado E, Castaño G, Díaz de Greñu C, Prieto J, Díaz FJ (2002) Prevalencia de diabetes mellitus e intolerancia a la glucosa en población entre 30 y 75 años en Asturias (España). Rev Clin Esp 202:421-427 
48. Mokdad AH, Bowman BA, Ford ES, Vinicor F, Marks JS, Koplan JP (2001) The continuing epidemics of obesity and diabetes in the United States. JAMA 286:1195-1200

49. Garancini M (1996) Age-specific incidence and duration of known diabetes. The Cremona Study. Diabetes Care 19: 1279-1282

50. National Center for Chronic Disease Prevention and Health Promotion (1999) Statistics. Diabetes Surveillance. Centers for Disease Control and Prevention. Available from http://www.cdc.gov/diabetes/statistics/surv199/chap2/table21. htm, accessed 8 March 2002

51. Figuerola D, Recasens A, Castell C et al. (1992) La asistencia al diabético en Cataluña. Estudio en una muestra de población. Med Clin (Barc) 99:90-95

52. Mur T, Franch J, Morato J, Mena A, Villarubias M, Llobera A (1995) Macroangiopatia en la diabetes tipo II. El estudio Raval Sud. Aten Primaria 16:67-72

53. Morató J, Franch J, Carrillo R, Via M, Herrera A, Valerio LI (1995) Cronología de las complicaciones en la diabetes del adulto. El estudio Raval Sud. An Med Interna 12:431-437

54. Fernandez de Mendiola Espino J, Iza Padilla A, Lasa Beitia I, Ibanez Perez F, Aguirrezabala Jaca JR, Aizpuru Barandiaran $\mathrm{M}$ et al. (1996) Evaluación de la población diabética tipo II atendida en un equipo de atención primaria. Aten Primaria 17:432-438

55. Goicolea I, Mancha A, Perez B, Villar G, Ugarte E, Vazquez JA (1996) Prevalencia de complicaciones de la diabetes en un area sanitaria de Vizcaya. Endocrinología 43:337-341

56. Lara N, Franch J, Morató J, Egido A, Puig J, Castillejo J (1996) La dislipemia en la diabetes tipo II ¿Un factor de riesgo para la macroangiopatía? Aten Primaria 18:17-24

57. Robles NR, Cid MC, Roncero F, Pizarro JL, Sánchezcasado E, Pérez-Miranda M (1996) Incidencia de nefropatía diabética en la provincia de Badajoz durante el periodo 1990-1994. An Med Interna 13:572-575

58. Gonzalez-Clemente JM (1997) Diabetes mellitus no dependiente de insulina: asistencia en un area de Barcelona. Med Clin (Barc) 108:91-97

59. Esmatjes E, Goicolea I, Cacho L, Pablos PL de, Rodríguez R, Roche MJ (1997) Nefropatía en la Diabetes mellitus tipo 2: prevalencia en España. Avances Diabetol 13:29-35

60. Cabezas Cerrato J (1998) The prevalence of clinical diabetic polineuropathy in Spain: a study in primary care and hospital clinic groups. Diabetologia 41:1263-1269

61. Bundó M, Aubá J, Vallés R, Torner O, Perez AM, Massons J (1998) Arteriopatía en la diabetes mellitus tipo 2. Aten Primaria 22:5-10

62. Zancada F, Mena P, Campillo JE, Hernández R, Perez-Aloe MT (1999) Factores de riesgo vascular en la diabetes mellitus no insulinodependiente. Correlación entre albuminuria y hemoglobina glicada. An Med Interna 16:181-185

63. Diabetes Draftin Group (1985) Prevalence of small vessel and large vessel disease in diabetic patients from 14 centres. The Word Health Organization Multinational Study of Vascular Disease in Diabetes. Diabetologia 28:615-640

64. Chi ZS, Lee ET, Lu M, Keen H, Bennet PH, the WHO Multinational Study Group (2001) Vascular disease prevalence in diabetic patients in China: standarised comparison with the 14 centres in the WHO multinational study of vas- cular disease in diabetes. Diabetologia 44 [Suppl 2]:8286

65. UKPDS Group (1990) UK prospective diabetes study 6. Complications in newly-diagnosed type 2 diabetic patients and their association with different clinical and biochemical risk factors. Diabetes Research 13:1-11

66. Uusitopa M, Siitonen O, Pyorala K, Aro a, Hersio K, Penttila I, Vouitilainem E (1985) The relationship of cardiovascular risk factors for the prevalence of coronary heart disease in newly-diagnosed Type II (non-insulindependent) diabetes. Diabetologia 28:653-659

67. Medical Research Council Working Party (1985) MRC trial of treatment of mild hypertension. Principal results. BMJ 291:97-104

68. Beach KW, Strandness DE (1980) Arteriosclerosis and associated risk factors in insulin-dependent and non-insulin dependent diabetes. Diabetes 29:882-888

69. Aro A, Voulainen E, Uusutupa M, Siitonen O, Korhonen T, Pyrola K (1981) Abnormalities of serum and lipoprotein lipids in newly-diagnosed type 2 diabetes. Diabetologia 21:244-260

70. Santen RJ, Willis PW, Fajans SS (1972) Atherosclerosis in diabetes mellitus. Correlations with serum lipid levels, adiposity and serum insulin levels. Arch Intern Med 130: 833-843

71. Hernández JM, Costa B, Diabetes Study Group (ABS de Falset) (1991) Diagnostico de salud de la población diabética en la comarca del Priorat (Tarragona). Aten Primaria 8:668-674

72. Calle Pascual AL, Calle Hernandez JR (1993) Factores de riesgo cardiovascular y tratamiento con insulina en pacientes diabéticos tipo II en quienes ha fracasado el tratamiento con hipoglucemiantes orales. Med Clin (Barc) 101:165167

73. Baena JM, Oller M, Martin R, Nicolau N, Altes A, Iglesias C (1999) Impacto de los nuevos criterios diagnósticos propuestos por la Asociación Americana de Diabetes (ADA 97) sobre la prevalencia diagnóstica de diabetes mellitus tipo 2. Aten Primaria 24:97-100

74. Serna MC, Madrid M, Cruz I, Gasco E, Ribelles M, Serra LI (1999) Estimación de la prevalencia de diabetes mellitus en seis comarcas de la provincia de Lleida. Endocrinología 46:83-86

75. American Diabetes Association (2001) Management of dyslipemia in adults with diabetes. Diabetes Care 24 [Suppl 1]:S58-S51

76. Pyorala K, Laasko M, Uusitupa M (1987) Diabetes and atherosclerosis: an epidemiologic view. Diabetes Metab Rev 3:463-524

77. Jarret RJ (1992) Risk factors for coronary heart disease in diabetes mellitus. Diabetes 41 [Suppl 2]:1-3

78. Fuller JH, Stevens LK, Wang SL, the WHO Multinational Study Group (2001) Risk factors for cardiovascular mortality and morbidity: the WHO multinational study of vascular disease in diabetes. Diabetologia 44 [Suppl 2]:S54-S64

79. Evans JMM, Wang J, Morris AD (2002) Comparison of cardiovascular risk between patients with type 2 diabetes and those who had had a myocardial infarction: cross sectional and cohort studies. BMJ 324:939-944 